\title{
Characterization of seasonal and chemotypical variability in the essential oil from leaves of Annona neosalicifolia H. Rainer (Annonaceae)
}

\author{
Tiago Juliano Tasso de Souza ${ }^{1,}{ }^{*}$, (D) Gilberto Dolejal Zanetti², (D) Miriam Anders Apel ${ }^{3}$, (D) Amélia \\ T. Henriques ${ }^{3}$, (D) Melânia Palermo Manfron ${ }^{1}$ \\ ${ }^{1}$ Department of Industrial Pharmacy, Center of Health Sciences, Santa Maria Federal University, Avenida Roraima, 1000, \\ Camobi, Santa Maria, RS, BRAZIL \\ ${ }^{2}$ Campus Macaé, Rio de Janeiro Federal University, Macae, RJ, BRAZIL \\ ${ }^{3}$ Pharmaceutical Sciences Post-Graduate Program, Faculty of Pharmacy, Rio Grande do Sul Federal University, Avenida \\ Ipiranga, 2752, Porto Alegre, RS, BRAZIL
}

*Corresponding author. Email: tiago.souza@ufrgs.br

Submitted:01.06.2021; Accepted: 13.09.2021

\section{Abstract}

The essential oil (EO) from leaves of Annona neosalicifolia $\mathrm{H}$. Rainer (Annonaceae) obtained from two chemotypes in the southern Brazilian Atlantic Rainforest was analysed both by GC-FID and GC-MS. Forty compounds were identified, accounting for 95.9 to $99.5 \%$ of the total oil in each sample. The VOs were characterized by the predominance of sesquiterpenes in all samples, being main compounds bicyclogermacrene (13.9-41.8\%) and beta-caryophyllene (9.3-26.3\%); germacrene D was also found in high amounts, but its concentration was more variable. Monoterpene compounds were absent in the summer and fall samples, with higher concentrations in winter samples (6.1-7.4\% for $\alpha$-pinene and $6.4-11.2 \%$ for $\beta$-pinene). EO from chemotype II was characterized by a high concentration of the sesquiterpene alcohol $(E)$-nerolidol (36.3\%), which was absent or in trace amounts in chemotype I. The characterization of these seasonal and individual variations in the chemical composition of the essential oil from A. neosalicifolia may have agronomical implications and may be important in the understanding and delimitation of the metabolic plasticity of the highly variable taxon $A$. emarginata as well.

Keywords: Annonaceae, Annona neosalicifolia, Essential Oil, Seasonal Variation, (E)-nerolidol

\section{Introduction}

The Annonaceae family of plants comprises about 120 genera and approximately 2300 mainly forest species around the world, twenty-nine genera comprising ca 260 species in Brazil (Barroso et al., 1978; Maas et al., 2001). Previous reports have identified species from this family as a source for terpenic compounds, specially diterpenes (de Andrade et al., 2004; Moreira et al., 2003), mono- and sesquiterpene rich essential oils (Tairu et al., 1999), isoquinoline alkaloids (Fechine et al., 2002; Jumana et al., 2000; Lima et al., 2004; Moreira et al., 2003), steroids, polyphenols, flavonoids (Moreira et al., 2003), fatty acids and acetogenins (de Andrade et al., 2004; Pontes et al., 2004). The acetogenins uvariamicin-I, solamine, and goniogenin were isolated from the hexane extract from leaves of Rollinia laurifolia (Nascimento et al., 2003).

Volatiles were reported from Annonaceae species, especially from Cananga odorata (Ylang-Ylang) and edible species in the genus Annona (Campos et al., 2014; Felipe G Campos et al., 2019a, Felipe G Campos et al., 2019b; Jirovetz et al., 1998; Pino, 2000; Thang et al., 2013; Wyllie et al., 1987). The most commonly reported volatiles were terpenic in origin: $\alpha$-pinene, $\beta$-pinene, limonene, $\beta$-caryophyllene, $p$-cymene, and caryophyllene oxide, which are found in many oils and, therefore, have no special taxonomic value. Other compounds, however, seem to be restricted to some taxa in the family: argentilactone in Annona haematantha; the sesquiterpene 1,5-epoxysalvyal-4(14)-ene, with the rare isodaucane nucleus, in Artabotrys 
species; and the aromatic compound 2,4,5-trimetoxystyrene in Pachypodanthium staudii (Founder et al., 1997; Fournier et al., 1999). Previously containing ca. 65 South American, Caribbean, and Mexican species, the genus Rollinia was merged into Annona (Leboeuf et al., 1980; Rainer, 2006). From the (former) Rollinia genus, the fruits of $R$. mucosa have had their volatile chemical constituents described, $\alpha$-pinene, $\beta$-pinene, and $\beta$-caryophyllene being the main compounds (Pino, 2000), while in Rollinia leptopetala cis-4-thujanol (17.37\%), $\alpha$-terpineol (8.42\%), germacrene D (7.72\%), bicyclogermacrene (22.47\%), and (E)-caryophyllene $(6.63 \%)$ were the main volatiles (Costa et al., 2008).

Annona neosalicifolia H. Rainer (syn. Rollinia salicifolia Schltdl., 'ariticunzeiro') is a 7-20-meters tall tree native to Rio Grande do Sul state (RS), Southern Brazil, and Northeast Argentina, on the southern range of the Atlantic Forest. The species produces edible fruits which are consumed in natura (Brack et al., 2020) and commercialized in street markets in southern Brazil. In folk medicine, the decoction of stem barks from $A$. neosalicifolia are used in the treatment of conjunctivitis; infusion of leaves are used as 'detoxifying agent'; and seed decoctions are used for killing Pediculus humanus capitis. Alkaloids, triterpenes, steroids, anthraquinones, anthocyanins, and essential oils were characterized in a phytochemical screen of leaves from this species (Walker et al., 2003).

Some authors synonymize $A$. neosalicifolia in A. emarginata (Maas e tal., 1992), whose variety "terra-fria" is extensively used as a rootstock for the cultivation of the economically promising atemoya fruit (A. $x$ atemoya) in southeastern Brazil. The volatile chemistry of that variety was studied and compared with that of another A. emarginata variety not suitable as rootsock under the premise that volatiles may be important for the success of the transplant activity (Campos et al., 2014; Campos, Vieira, Baron, et al., 2019; Campos, Vieira, Santos, et al., 2019; Mimi, 2019).

Considering that the chemical composition of essential oils can vary significantly as a function of climatic conditions, vegetative stage, and a specimen genetic constitution, this work aims to describe for the first time the chemical composition of the leaf VOs from two chemotypes of Annona neosalicifolia accounting also for seasonal patterns.

\section{Materials and Methods}

\section{Plant material}

Leaves of Annona neosalicifolia H.Rainer were sampled from two chemotypes, in the municipality of São José das Missões, Rio Grande do Sul State, Brazil, in January, March, and July (2005) for chemotype I and July (2005) for chemotype II. Voucher material (SMDB 10.224) was deposited at the Herbarium of the Department of Biology of Universidade Federal de Santa Maria UFSM, Santa Maria-Brazil.

\section{Extraction of the essential oils}

The EO from leaves was obtained by hydrodistillation for 4 hours in a Clevenger-type apparatus. The essential oil percentage yield (\%) was calculated as volume of oil and the weight of fresh material $(\mathrm{w} / \mathrm{v})$. The oil was recovered in ethyl ether and stored under refrigeration after removal of the solvent.

\section{Analysis of the essential oils}

The EO from each sample was submitted to GC-FID and GC/MS. GC-FID analysis was performed in a Shimadzu GC17-A system with a DB-5 capillary fused silica column ( $25 \mathrm{~m} \times 0.25 \mathrm{~mm}$ i.d., $0.25 \mu \mathrm{m}$ film thickness). Injector and detector temperatures were $220 \stackrel{\circ}{\circ}$ and $250 \circ \mathrm{C}$, respectively. Column temperature was programmed

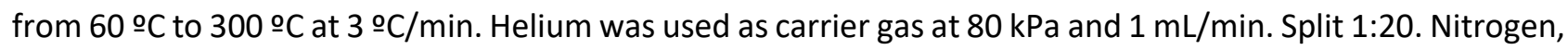


synthetic air, and hydrogen (1:1:10) as auxiliary gases. The percentage compositions of the individual components were obtained from electronic integration measurements using flame ionization detection (FID, $250^{\circ} \mathrm{C}$ ). GC/MS analysis was performed the same chromatographic system, with a Shimadzu QP-5000Quadrupole MS detector, operating with $70 \mathrm{eV}$ ionization energy. Helium as carrier gas, $1 \mathrm{ml} / \mathrm{min}$ flow, split. Spectra were recorded between 30 and $400 \mathrm{~m} / \mathrm{z}$. Compounds were identified by comparison of Retention Index (determined using C9-C22 alkanes) and mass spectra with data from the NIST Mass Spectral Library (National Institute of Standards and Technology) or with spectral data from the literature (Adams, 2007).

\section{Multivariate analysis}

Percentage data missing or reported as traces was inputted using the multRepl() function of the R package zCompostions (Palarea-Albaladejo and Martín-Fernández, 2015) and PCA was performed with the option logratio 'CLR' of the function pca() in the R package mixOmics (Rohart et al., 2017).

\section{Results and Discussion}

A total of 40 chemical compounds were identified in the EO from the leaves of A. neosalicifolia. 95.9 to $99.5 \%$ of the total components of each oil were identified and the yield of oil obtained ranged between 0.1 and $0.16 \%$ in the different samples as in Table 1 . Overall, oils from this species were characterized by the predominance of sesquiterpenes. The hydrocarbon sesquiterpenes $\beta$-caryophyllene (9.3-26.3\%) and bicyclogermacrene (13.9-41.8\%) were among the main compounds in all samples; germacrene $D$ was found in expressive amounts, too, in all samples from the chemotype I. In the second chemotype, the proportion of this compound was approximately five-fold lesser than those obtained in chemotype I (only $4.5 \%$ ). It is also remarkable the complete absence of monoterpene compounds in the oils obtained in January (Summer) and March (Fall), the beginning and the end of the fruiting period, respectively. However, monoterpene compounds, mainly the hydrocarbons $\alpha$-pinene (6.7-7.4\%) and $\beta$-pinene (6.4-11.2\%) were found in relatively high concentrations in the samples obtained during Winter (July), when this species was in a sterile period. Oxygenated terpenes were almost absent, except for the second chemotype, where the concentration of the oxygenated aliphatic sesquiterpene $(E)$-nerolidol was $36.3 \%$, contrasting with $0-0.7 \%$ in chemotype I. For a long period between Winter and Spring (August-October) the deciduous species did not exhibit any leaves and no Spring samples were obtained for this study.

The most abundant hydrocarbon sesquiterpene in the essential oil from leaves of A. neosalicifolia, considering all analyses performed, was the compound bicyclogermacrene; it is a common compound in some Xylopia, Fitzalania, and Uvaria species (Brophy et al., 2004; Maia et al., 2005), but is rarely found as the main compound in oils from other Annonaceae. Another compound present in a high concentration, $\beta$ caryophyllene (and its oxidized derivative caryophyllene oxide) seems to be the more widespread sesquiterpene in this family, having no taxonomic value at the tribal and generic levels (Fournier et al., 1997a, 1997b, 1997c). Germacrene D, also found in high amounts, is a relatively common, easily oxidizable hydrocarbon sesquiterpene that can give origin to several other compounds after rearrangement, most commonly selinane and cadinane derivatives (Bülow and König, 2000). Compositional PCA applying centered logratio, used as an exploratory tool, highlighted the importance of pinenes in the winter samples, the preponderance of $(E)$-nerolidol in the chemotype II and TMTT in both the chemotype II and the Fall sample of chemotype I (Figure 1).

In the second chemotype, the oxygenated sesquiterpene $(E)$-nerolidol was observed as the main compound. It is a known feed deterrent (Doskotch et al., 1980), an attractor for some insects, and also produced by flowers for pollination. In some plants, $(E)$-nerolidol is released after herbivore damage, when it acts as an 
attractor for carnivores, predators for the herbivore insects that caused the damage, characterizing tritrophic systems (Kappers et al., 2005). The same compound acts as a precursor for the biosynthesis of the homomonoterpene 4,8-dimethyl-1,3,7-nonatriene (DMNT), that is also released after herbivory. In the same way, the homologous diterpene compound geranyl-linalool can originate the homo-sesquiterpene 4,8,12trimethyltrideca-1,3,7,11-tetraene (TMTT), another important signaler in tritrophic systems (Degenhardt and Gershenzon, 2000; Schnee et al., 2002). Two trace compounds were detected with the mass spectrum and retention times similar to those published for DMNT and TMTT. The presence of (E)-nerolidol, DMNT, and TMTT suggests that the specimens could be under biotic stress and, indeed, some Annona species can be attacked by gall coccids, which may alter their metabolism in a manner not yet well understood. These alterations can occur in attacked leaves, where gall formation occurs (Soares et al., 2000), but also in the whole plant, preventing herbivore attack to the healthy leaves. In Annonaceae species, the occurrence of $(E)$ nerolidol is not widespread; it has been identified in some genera, such as Cleistopholis, Dennettia, Monodora, Xylopia, and Pachypodanthium, but in very low concentration only (Boyom et al., 2003; Brophy et al., 2004).

The essential oil from most Annonaceae species is composed of substances of terpenic origin (mono- and sesquiterpenes). Compounds originated in other metabolic routes can occur, sometimes, such as phenylpropanoids and aliphatic derivatives, especially in Annona and Asimina species. As described for this family, the chemical composition of the essential oil varies in different organs: hydrocarbon monoterpenes in oils from fruits and seeds; hydrocarbon sesquiterpenes in oils from leaves; and oxygenated sesquiterpenes in oils from the stem and root barks (Fournier et al., 1999). In A. neosalicifolia, two factors seem to play a significant role in the chemical compositions of VOs. On one hand, the presence or absence of monoterpenes showed a seasonal dependency. On the other hand, each chemotype showed a very different profile on the sesquiterpene fraction, even under the same edaphoclimatic conditions, pointing to a genetically controlled character.

Descriptions of the chemical composition of essential oils sometimes neglect the importance of seasonal variations for characterizing these products; however, an evaluation of those variations allows a better understanding of the metabolic plasticity of a given species in time. This knowledge, allied to the investigation of different populations would allow also the identification of chemotypes, and it should give the investigator more reliability when performing samplings aimed at a specific metabolite or metabolite ensemble.

The taxonomy of $A$. neosalicifolia is disputed at both generic and specific levels. On the generic level, the previously well-defined Rollinia was merged into Annona (Rainer, 2006). On the specific level, some confusion exists, too. The section Rolliniella in the former genus Rollinia, used to be composed of eight taxa: $R$. ulei in the Peruvian Amazon Forest, and R. salicifolia, R. rugulosa, R. occidentalis, R. glaziovii, R. emarginata, $R$. hassleriana, and $R$. intermedia, reported to occur in the Atlantic Forest between southern and south-eastern Brazil, north-eastern Argentina, and Paraguay (Záchia, 1994). After a brief synonymization under $R$. emarginata sesu lato, due to the impossibility of differentiation based on purely quantitative morphological traits (Maas et al., 1992), four species were delimited again from the new highly variable Atlantic taxon $R$. emarginata s.l.: R. emarginata sensu stricto, R. salicifolia, R. rugulosa and $R$. maritima (Záchia and Irgang, 1996), finally transferred to Annona as A. emarginata, A. neosalicifolia, A. rugulosa, and A. maritima, together with $A$. neoulei based on phylogenetics (Rainer, 2006). The concepts $R$. occidentalis and $R$. glaziovii remained merged in $A$. rugulosa while $R$. hassleriana and $R$. intermedia remained merged in A. emarginata s.s. The distribution range of $A$. neosalicifolia borders that of $A$. maritima to the east, in the coastal strip of RS, in southern Brazil, and that of $A$. emarginata s.s. to the west, in Argentina, overlapping with that of $A$. rugulosa 
in the western regions of Rio Grande do Sul and Santa Catarina states (Záchia and Irgang, 1996). Even though the four species were resurrected from A. emarginata s.l. (Záchia and Irgang, 1996) some authors consider them in the sensu lato (Maas et al., 1992; Mendes-Silva et al., 2020) and as a vulnerable taxon in RS (Rio Grande do Sul, 2014).

The description of two chemotypes in A. neosalicifolia has possible agricultural, taxonomical, and ecological implications worth being further studied. The agricultural aspect is related to the use of $A$. emarginats s.s. for grafting economically important Annona spp. A. emarginata s.s. occurs in Argentina, Paraguay, and southeastern Brazil, where, in São Paulo, several compositions were reported for two varieties, 'mirim' and 'terrafria'. The variety A. emarginata 'terra-fria', highly resistant to stem borers, pests, and diseases (Kavati and Watanabe, 2010) is economically important because it is the most used rootstock for the cultiation of atemoya ( $A . x$ atemoya), a plant whose fruit has great economic potential due to its well-accepted organoleptic characters. The two varieties of $A$. emarginata s.s. native in São Paulo (where none of $A$. maritima, $A$. neosalicifolia, or $A$. rugulosa were reported), can be differentiated by their volatiles: myrcene ('terra-fria':1-1\% x 'mirim':12-14\%), linalool (1-2\% x 10-16\%), (E)-caryophyllene (13-27\% x 6-10\%), and thujene (3-11\% x 1-1\%) (Mimi, 2019). Other reports referred (E)-caryophyllene (29.29\%), (Z)-caryophyllene (16.86\%), $\gamma$-muurolene (7.54\%), $\alpha$-pinene $(13.86 \%)$, and tricyclene $(10.04 \%)$ as main volatiles in $A$. emarginata var. 'terra-fria' (Campos et al., 2014) and, in the EO from leaves of the rootstock for grafted $A . x$ atemoya, $\beta$-selinene (12.63\%), $\alpha$-selinene (12.21\%), $\beta$-elemene $(9.66 \%)$, spathulenol $(7.25 \%), \alpha$-pinene (5.55\%), (E)-caryophyllene (5.39\%) (Campos, Vieira, Baron, et al., 2019b). The volatile chemical profile of the rootstock may influence the success of grafting, probably due to antioxidant, antiradical, and antibiotic activities (Campos, Vieira, Baron, et al., 2019a,b), so it is reasonable to hypothesize that if $A$. emarginata s.s. and $A$. neosalicifolia are actually the same species, the chemical composition of $A$. neosalicifolia chemotype I/ qualifies it as a new chemotype, different from any reported for $A$. emarginata s.s. and could be tested as an alternative rootstock for grafting $A$. $x$ atemoya.

Both chemotypes of A. neosalicifolia were sampled in a $500 \mathrm{~m}$ high remnant of the Seasonal Semideciduous or Mixed Ombrophilous Forest, the RS component of the Atlantic Forest, a Biome with a biodiversity 8 times greater than that of the Amazon Forest, but from which less than 13\% still exists (Galindo-Leal and Gusmão Câmara, 2003). In RS, the extent of destruction of the Atlantic Forest is even bigger and only $7.5 \%$ of the original forest has not fallen to the monocultures such as soybean and corn (Rio Grande do Sul, 2020). Finding industrial and economically important chemotypes of a big deciduous native tree, such as one with VOs composed of almost half or even higher percentages of a highly active compound, (E)-nerolidol (Chan et al., 2016), could likely enhance that region's economic chain if adequately exploited.

While A. cherimola (cherimoya), A. muricata (soursop), A. squamosa (sweetsop), and A. $x$ atemoya are cultivated in more tropical regions and are very well accepted for consumption in natura, as juices or jams (Braga Sobrinho, 2014), the expansion of the Annonaceae market in Brazil depends either on the development of research to extend the shelf life of these fruits, allowing them to be processed and reach markets more distant from the productive areas (São José et al., 2014), or on the development of more marketable varieties, which could help to reduce the economic dependency on the monocultures. Fruits from Annonaceae species in the Brazilian Cerrado have been transformed into cereal bars and liquors (Oliveira, 2015,2019 ), and several species were evaluated for propagation by cuttings (Scaloppi Junior and Martins, 2014). Specimens of $A$. rugulosa and $A$. neosalicifolia have a very similar habit, height (up to $20 \mathrm{~m}$ ), and very similar leaf shape (Záchia and Irgang, 1996), differing by a characteristic glossiness in the abaxial surface of A. rugulosa and the shape of galls in the leaf, which are characteristic for each species. Globose $(4 \times 4 \mathrm{~mm})$ 
galls are usually found in the leaves of $A$. rugulosa while cylindric $(1-2 \times 6 \mathrm{~mm})$ ones are found in the leaves of $A$. neosalicifolia (similar galls are sometimes found in $A$. emarginata). A possible link between these galls and the production of volatiles in A. neosalicifolia will be discussed elsewhere (de Souza, T.J.T., personal communication).

The volatile profile of a plant, besides acting in the defense strategy and attraction of pollinators for reproduction and survival, may also show pharmacological properties with economic importance. It was suggested that not only the parentals but also the rootstock used in propagation through cuttings could influence the volatile profile of a cultivated Annonaceae (Campos, Vieira, Baron, et al., 2019a,b). Also, despite the fruit volatiles being very different from the respective leaf volatiles (de Sousa Galvão et al., 2020; Neta et al., 2019; Pino, 2000; Santana et al., 2017; Xu et al., 2016), further analyses of the fruits from these two chemotypes of $A$. neosalicifolia, could reveal if the differences here reported are reflected in those edibles and if they somehow affect their sensorial properties. On the other hand, further study of the interaction of each chemotype with the species' characteristic galls and their gall-inducing insects could reveal important trophic or signaling systems possibly exploitable in the cultivation of Annonaceae through the aforementioned rootstock properties.

To the best of our knowledge, this is the first report on the chemical composition of the EO from leaves of two chemotypes of $A$. neosalicifolia presented with its seasonal variation.

Table 1. Chemical composition of the essential oils from the leaves of Annona neosalicifolia H.Rainer.

\begin{tabular}{|c|c|c|c|c|c|c|c|}
\hline \multirow[b]{2}{*}{$\mathbf{K} \mathbf{I}^{\mathbf{a}}$} & \multirow[b]{2}{*}{$\mathbf{R I}^{\mathbf{b}}$} & \multirow[b]{2}{*}{$\mathrm{IM}^{\mathrm{c}}$} & \multirow[b]{2}{*}{ Compound } & \multicolumn{3}{|c|}{ Chemotype I } & \multirow{2}{*}{$\begin{array}{c}\text { Chemotype II } \\
\text { Winter }\end{array}$} \\
\hline & & & & Summer & Fall & Winter & \\
\hline 922 & 930 & $\mathrm{I}, \mathrm{M}$ & $\alpha$-thujene & - & - & 0.5 & 0.2 \\
\hline 925 & 932 & $\mathrm{I}, \mathrm{M}$ & $\alpha$-pinene & - & - & 6.1 & 7.4 \\
\hline 960 & 969 & $\mathrm{I}, \mathrm{M}$ & sabinene & - & - & 0.7 & 1.4 \\
\hline 963 & 974 & $\mathrm{I}, \mathrm{M}$ & $\beta$-pinene & - & - & 6.4 & 11.2 \\
\hline 979 & 988 & $\mathrm{I}, \mathrm{M}$ & myrcene & - & - & 0.6 & 1.1 \\
\hline 1017 & 1024 & $\mathrm{I}, \mathrm{M}$ & limonene & - & - & 0.2 & 0.3 \\
\hline 1037 & 1044 & $\mathrm{I}, \mathrm{M}$ & $(E)$ - $\beta$-ocimene & - & - & 0.3 & - \\
\hline 1091 & 1095 & $\mathrm{I}, \mathrm{M}$ & linalool & - & $\operatorname{tr}^{d}$ & - & $\operatorname{tr}$ \\
\hline 1107 & 1114 & $\mathrm{I}, \mathrm{M}$ & DMNT e & - & - & - & $\operatorname{tr}$ \\
\hline 1164 & 1174 & $\mathrm{I}, \mathrm{M}$ & terpinen-4-ol & - & - & - & 0.2 \\
\hline 1325 & 1335 & $\mathrm{I}, \mathrm{M}$ & $\delta$-elemene & $\operatorname{tr}$ & 0.1 & 0.1 & $\operatorname{tr}$ \\
\hline 1358 & 1374 & $\mathrm{I}, \mathrm{M}$ & $\alpha$-copaene & 0.4 & 0.1 & 0.4 & $\operatorname{tr}$ \\
\hline 1371 & 1387 & $\mathrm{I}, \mathrm{M}$ & $\beta$-bourbonene & $\operatorname{tr}$ & 0.1 & 0.2 & $\operatorname{tr}$ \\
\hline 1372 & 1387 & $\mathrm{I}, \mathrm{M}$ & $\beta$-cubebene & 0.3 & 0.1 & 0.3 & $\operatorname{tr}$ \\
\hline 1374 & 1398 & $\mathrm{I}, \mathrm{M}$ & $\beta$-elemene & 2.9 & 1.2 & 3.0 & 0.6 \\
\hline 1401 & 1417 & $\mathrm{I}, \mathrm{M}$ & (E)- $\beta$-caryophyllene & 26.3 & 9.3 & 23.9 & 15.1 \\
\hline 1433 & 1452 & $\mathrm{I}, \mathrm{M}$ & $\alpha$-humulene & 3.3 & 2.3 & 3.2 & 2.3 \\
\hline 1439 & 1458 & $\mathrm{I}, \mathrm{M}$ & allo-aromadendrene & 0.3 & 0.3 & 0.4 & $\operatorname{tr}$ \\
\hline 1460 & 1484 & $\mathrm{I}, \mathrm{M}$ & germacrene D & 22.9 & 25.4 & 19.9 & 4.5 \\
\hline 1471 & 1489 & $\mathrm{I}, \mathrm{M}$ & $\beta$-selinene & - & 0.1 & 0.1 & - \\
\hline 1476 & 1500 & $\mathrm{I}, \mathrm{M}$ & bicyclogermacrene & 34.2 & 41.8 & 27.0 & 13.9 \\
\hline 1479 & 1500 & $\mathrm{I}, \mathrm{M}$ & $\alpha$-muurolene & 0.3 & $\operatorname{tr}$ & $\operatorname{tr}$ & $\operatorname{tr}$ \\
\hline 1482 & 1508 & $\mathrm{I}, \mathrm{M}$ & germacrene $\mathrm{A}$ & 2.2 & 3.6 & 2.8 & 0.5 \\
\hline
\end{tabular}




\begin{tabular}{|c|c|c|c|c|c|c|c|}
\hline 1493 & 1513 & $\mathrm{I}, \mathrm{M}$ & $\gamma$-cadinene & $\operatorname{tr}$ & $\operatorname{tr}$ & $\operatorname{tr}$ & - \\
\hline 1598 & 1503 & $\mathrm{I}, \mathrm{M}$ & germacrene $\mathrm{C}^{\mathrm{f}}$ & - & $\operatorname{tr}$ & $\operatorname{tr}$ & - \\
\hline 1499 & 1522 & $\mathrm{I}, \mathrm{M}$ & $\delta$-cadinene & 0.9 & 1.6 & 0.7 & 0.3 \\
\hline 1508 & 1533 & $\mathrm{I}, \mathrm{M}$ & $(E)$-cadina-1,4-diene & - & $\operatorname{tr}$ & $\operatorname{tr}$ & - \\
\hline 1514 & 1537 & $\mathrm{I}, \mathrm{M}$ & $\alpha$-cadinene & - & $\operatorname{tr}$ & $\operatorname{tr}$ & - \\
\hline 1542 & 1559 & $\mathrm{I}, \mathrm{M}$ & germacrene B & - & 0.3 & $\operatorname{tr}$ & - \\
\hline 1543 & 1548 & $\mathrm{I}, \mathrm{M}$ & elemol & - & 0.1 & - & - \\
\hline 1549 & 1561 & $\mathrm{I}, \mathrm{M}$ & $(E)$-nerolidol & - & 0.7 & $\operatorname{tr}$ & 36.3 \\
\hline 1552 & 1574 & $\mathrm{I}, \mathrm{M}$ & germacrene D-4-ol & - & $\operatorname{tr}$ & $\operatorname{tr}$ & 0.2 \\
\hline 1561 & 1577 & $\mathrm{I}, \mathrm{M}$ & spathulenol & 0.9 & 3.7 & 0.8 & 0.9 \\
\hline 1563 & 1590 & $\mathrm{I}, \mathrm{M}$ & TMTT g & - & 1.7 & $\operatorname{tr}$ & - \\
\hline 1566 & 1582 & $\mathrm{I}, \mathrm{M}$ & caryophyllene oxide & $\operatorname{tr}$ & 0.5 & 0.4 & 0.6 \\
\hline 1573 & 1590 & $\mathrm{I}, \mathrm{M}$ & globulol & 0.7 & 0.7 & 0.3 & 0.4 \\
\hline 1582 & 1585 & $\mathrm{I}, \mathrm{M}$ & epi-globulol ${ }^{\mathrm{h}}$ & 0.6 & 0.5 & 0.1 & $\operatorname{tr}$ \\
\hline 1612 & 1639 & $\mathrm{I}, \mathrm{M}$ & caryophylladienol & - & 0.1 & - & - \\
\hline 1625 & 1637 & $\mathrm{I}, \mathrm{M}$ & Isospathulenol ${ }^{\mathrm{h}}$ & 1.0 & 0.7 & $\operatorname{tr}$ & $\operatorname{tr}$ \\
\hline 1629 & 1640 & $\mathrm{I}, \mathrm{M}$ & $\tau$-cadinol+ $\tau$-muurolol & 1.0 & 1.3 & 0.4 & $\operatorname{tr}$ \\
\hline 1634 & 1644 & $\mathrm{I}, \mathrm{M}$ & $\alpha$-muurolol & $\operatorname{tr}$ & 0.1 & $\operatorname{tr}$ & $\operatorname{tr}$ \\
\hline 1642 & 1652 & $\mathrm{I}, \mathrm{M}$ & $\alpha$-cadinol & 1.0 & 1.2 & 0.7 & 0.4 \\
\hline & & \multicolumn{2}{|c|}{ Hydrocarbon Monoterpenes } & - & - & 14.8 & 21.6 \\
\hline & & \multicolumn{2}{|c|}{ Oxigenated Monoterpenes } & - & - & - & 0.2 \\
\hline & & \multicolumn{2}{|c|}{ Hydrocarbon Sesquiterpenes } & 95.0 & 86.3 & 82.0 & 37.2 \\
\hline & & \multicolumn{2}{|c|}{ Oxigenated Sesquiterpenes } & 5.2 & 11.3 & 2.7 & 38.8 \\
\hline & & \multicolumn{2}{|c|}{ (\%) Total identified } & 99.2 & 95.9 & 99.5 & 97.8 \\
\hline & & \multicolumn{2}{|c|}{ (\%) Yield i } & 0.12 & 0.10 & 0.16 & 0.14 \\
\hline
\end{tabular}

${ }^{a}$ Retention index relative to C9-C22 n-alkanes in a DB5 column; ${ }^{b}$ Literature Retention Index ( ${ }^{\mathrm{e}, \mathrm{g}}$ Snoeren, 2009; Vredenbregt, 2007; ${ }^{\mathrm{h}}$ Babushok et al, 2011; ${ }^{\text {}}$ de Souza et al, 2021; Adams, 2007 otherwise); c Identification method (I: Retention Index; M: Mass spectrum); $\mathrm{d}$ Traces; i Yield as a function of the volume of oil obtained and mass of fresh leaves ( $\mathrm{v} / \mathrm{w})$. DMNT (4,8-dimethylnona-1,3,7-triene), TMTT (4,8,12-trimethyltrideca-1,3,7,11-tetraene).

Figure 1. Compositional PCA of Essential Oils from the Leaves of Annona neosalicifolia H.Rainer

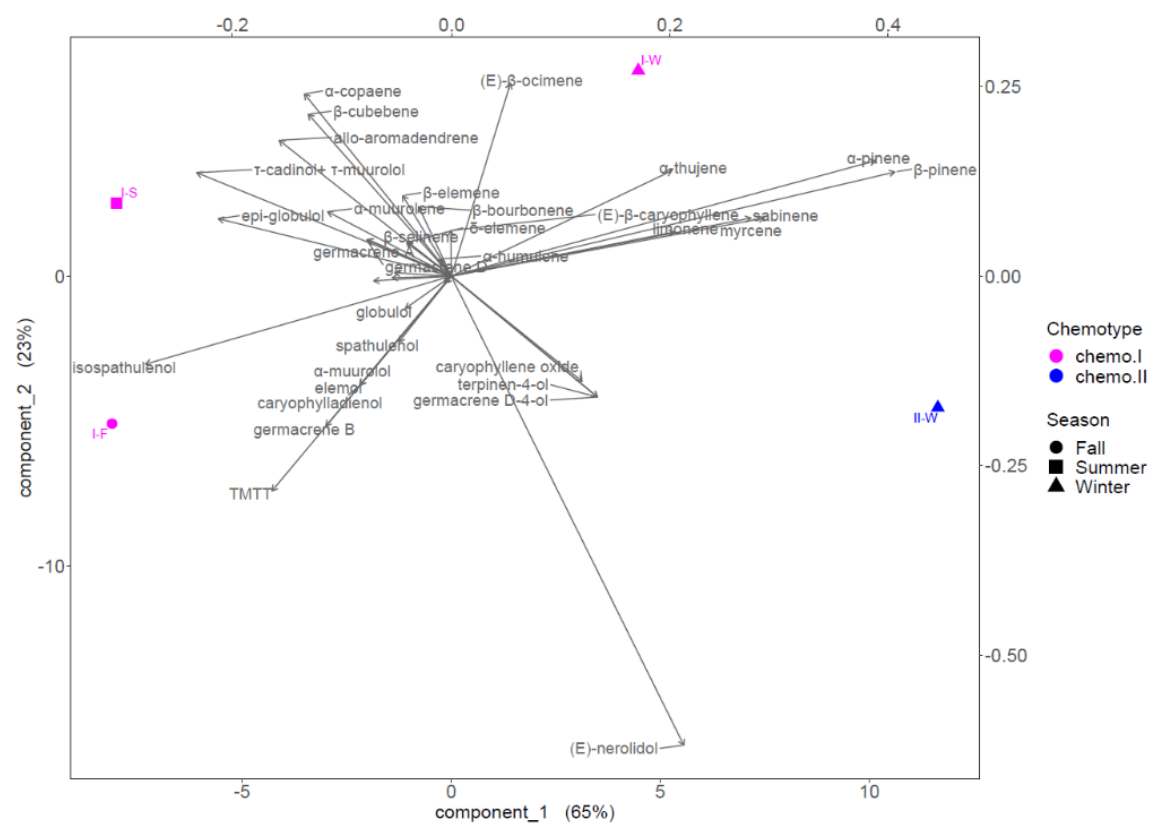




\section{Conclusion}

This species produces EO with compounds that are common in the Annonaceae family, where hydrocarbon sesquiterpenes predominated, especially $\beta$-caryophyllene, germacrene $D$, and bicyclogermacrene. In the winter, changes occurred in the chemical composition, mainly with the rise in the percentage of the monoterpenes $\alpha$-pinene and $\beta$-pinene. On the other hand, variations were observed on the percentages of the oxygenated sesquiterpene $(E)$-nerolidol which was very different between chemotypes.

\section{ACKNOWLEDGMENT}

This work was supported by Fundação de Amparo à Pesquisa do Estado do Rio Grande do Sul - FAPERGS and Conselho Nacional de Desenvolvimento Científico e Tecnológico - CNPq. Special thanks to Dr. Renata Pereira Limberger (PPGCF Universidade Federal do Rio Grande do Sul) for carefully revising the manuscript and for her invaluable contributions and to Dr. Gilbert Fournier (Faculté de Pharmacie - Université Paris-Sud) for kindly providing bibliographic information.

\section{CONFLICTS OF INTEREST}

The authors have no conflicts of interest to declare.

\section{REFERENCES}

Adams, R. P. (2007). Identification of essential oil components by gas chromatography/mass spectrometry. Allured publishing corporation Carol Stream, IL.

Babushok, V. I., Linstrom, P. J., \& Zenkevich, I. G. (2011). Retention indices for frequently reported compounds of plant essential oils. Journal of Physical and Chemical Reference Data, 40(4), 43101.

Barroso, G. M., Guimarães, E. F., Ichaso, C. L. F., Costa, C. G., Peixoto, A. L., \& Lima, H. C. (1978). Sistemática de angiospermas do Brasil (Vol. 1, Issue 2). Universidade de São Paulo São Paulo.

Boyom, F. F., Ngouana, V., Zollo, P. H. A., Menut, C., Bessiere, J. M., Gut, J., \& Rosenthal, P. J. (2003). Composition and anti-plasmodial activities of essential oils from some Cameroonian medicinal plants. Phytochemistry, 64(7), 1269-1275.

Brack, P., Köhler, M., Corrêa, C. A., Ardissone, R. E., Sobral, M. E. G., \& Kinupp, V. F. (2020). Frutas nativas do Rio Grande do Sul, Brasil: riqueza e potencial alimentício. Rodriguésia, 71.

Braga Sobrinho, R. (2014). Integrated production of Annonaceae in Brasil. Revista Brasileira de Fruticultura, 36(SPE1), 102-107.

Brophy, J., Goldsack, R., \& Forster, P. (2004). Essential oils from the leaves of some Queensland Annonaceae. Journal of Essential Oil Research, 16(2), 95-100.

Bülow, N., \& König, W. A. (2000). The role of germacrene D as a precursor in sesquiterpene biosynthesis: Investigations of acid catalyzed, photochemically and thermally induced rearrangements. Phytochemistry, 55(2), 141-168.

Campos, F. G., Baron, D., Marques, M. O. M., Ferreira, G., \& Boaro, C. S. F. (2014). Characterization of the chemical composition of the essential oils from Annona emarginata (Schltdl.) H. Rainer "terra-fria" and Annona squamosa L. Revista Brasileira de Fruticultura, 36(spe1), 202-208.

Campos, F. G., Vieira, M. A. R., Santos, A. A. Dos, Jorge, L. G., Marques, M. O. M., \& Boaro, C. S. F. (2019a). Chemical Diversity of Volatiles From Parents, Rootstock and Atemoya Hybrid. Journal of Agricultural Science, 11(271), 10-5539.

Campos, F. G., Vieira, M. M. A. R., Baron, D., Marques, M. O. M., Ferreira, G., \& Boaro, C. S. F. (2019b). Profile of Essential Oils From the Leaves of Annona Grafted. Journal of Agricultural Science, 11, 210-216.

Chan, W.-K., Tan, L. T.-H., Chan, K.-G., Lee, L.-H., \& Goh, B.-H. (2016). Nerolidol: a sesquiterpene alcohol with multifaceted pharmacological and biological activities. Molecules, 21(5), 529.

Costa, V. C. O., Tavares, J. F., Agra, M. F., Falcão-Silva, V. S., Facanali, R., Vieira, M. A. R., Marques, M. O. M., Siqueira- 
Júnior, J. P., \& Silva, M. S. da. (2008). Composição química e modulação da resistência bacteriana a drogas do óleo essencial das folhas de Rollinia leptopetala RE Fries. Revista Brasileira de Farmacognosia, 18(2), 245-248.

de Andrade, N. C., Barbosa-Filho, J. M., Da-Silva, M. S., da-Cunha, E. V. L., \& Maia, J. G. S. (2004). Diterpenes and volatile constituents from the leaves of Xylopia cayennensis Maas. Biochemical Systematics and Ecology, 32(11), 1055-1058.

de Sousa Galvão, M., de Santana, K. L., Nogueira, J. P., Neta, M. T. S. L., \& Narain, N. (2020). Method Optimization Study on Isolation of Volatile Compounds by Headspace Solid-Phase Microextraction (HS-SPME) from Custard Apple (Annona squamosa L.) Pulp. Journal of Analytical Sciences, Methods and Instrumentation, 10(03), 59.

de Souza, T. J., Bordignon, S. A., Apel, M. A., \& Henriques, A. T. (2021). Volatile constituents of Eupatorieae (Asteraceae). Compositional multivariate analysis of volatile oils from Southern Brazilian species in the subtribe Disynaphiinae. Phytochemistry, 186, 112734.

Degenhardt, J., \& Gershenzon, J. (2000). Demonstration and characterization of (E)-nerolidol synthase from maize: a herbivore-inducible terpene synthase participating in (3 E)-4, 8-dimethyl-1, 3, 7-nonatriene biosynthesis. Planta, 210(5), $815-822$.

Doskotch, R. W., Cheng, H.-Y., Odell, T. M., \& Girard, L. (1980). Nerolidol: An antifeeding sesquiterpene alcohol for gypsy moth larvae from Melaleuca leucadendron. Journal of Chemical Ecology, 6(4), 845-851.

Fechine, I. M., Navarro, V. R., da-Cunha, E. V. L., Silva, M. S., Maia, J. G. S., \& Barbosa-Filho, J. M. (2002). Alkaloids and volatile constituents from Duguetia flagellaris. Biochemical Systematics and Ecology, 30(3), 267-269.

Founder, G., Hadjiakhoondi, A., Roblot, F., Leboeuf, M., Cavé, A., \& Charles, B. (1997). Essential Oils of Annonaceae. Part VI. Volatile Constituents of the Essential Oils from Five Artabotrys Species. Journal of Essential Oil Research, 9(2), 145149.

Fournier, G., Hadjiakhoondi, A., Leboeuf, M., Cavé, A., \& Charles, B. (1997a). Essential oils of Annonaceae. Part VII. Essential oils of Monanthotaxis diclina (Sprague) Verdcourt and Unonopsis guatterioides RE Fries. Flavour and Fragrance Journal, 12(2), 95-98.

Fournier, G., Hadjiakhoondi, A., Leboeuf, M., Cavé, A., \& Charles, B. (1997b). Essential oils of Annonaceae. Part VIII. Volatile constituents of the essential oils from three Guatteria species. Journal of Essential Oil Research, 9(3), 275-278.

Fournier, G., Hadjiakhoondi, A., Roblot, F., Leboeuf, M., \& Cave, A. (1997c). Essential oils of Annonaceae. IV. Volatile constituents of the essential oils from five Artabotrys species. The Journal of Essential Oil Research, 9(2), 145-149.

Fournier, G., Leboeuf, M., \& Cavé, A. (1999). Annonaceae essential oils: a review. Journal of Essential Oil Research, 11(2), 131-142.

Galindo-Leal, C., \& Gusmão Câmara, I. (2003). Atlantic forest hotspot status. In The Atlantic forest of South America: biodiversity status, threats, and outlook. [State of the Hotspots.] (Vol. 1).

Jirovetz, L., Buchbauer, G., \& Ngassoum, M. B. (1998). Essential oil compounds of the Annona muricata fresh fruit pulp from Cameroon. Journal of Agricultural and Food Chemistry, 46(9), 3719-3720.

Jumana, S., Hasan, C. M., \& Rashid, M. A. (2000). Alakaloids from the stem bark of Miliusa velutina. Biochemical Systematics and Ecology, 28(5), 483-485.

Kappers, I. F., Aharoni, A., Van Herpen, T. W. J. M., Luckerhoff, L. L. P., Dicke, M., \& Bouwmeester, H. J. (2005). Genetic engineering of terpenoid metabolism attracts bodyguards to Arabidopsis. Science, 309(5743), 2070-2072.

Kavati, R., \& Watanabe, H. S. (2010). Anonáceas. História Da Fruticultura Paulista.

Leboeuf, M., Cavé, A., Bhaumik, P. K., Mukherjee, B., \& Mukherjee, R. (1980). The phytochemistry of the Annonaceae. Phytochemistry, 21(12), 2783-2813.

Lima, M. A., Barbosa-Filho, J. M., Merlic, C. A., Doroh, B. C., Maia, J. G. S., Silva, M. S., \& da-Cunha, E. V. L. (2004). 
Alkaloids and volatile constituents from Guatteria poeppigiana. Biochemical Systematics and Ecology, 32(3), 347-349.

Maas, P. J. M., de Kamer, H. M., Junikka, L., de Mello-Silva, R., \& Rainer, H. (2001). Annonnaceae from central-eastern Brazil. Rodriguésia, 52(80), 65-98.

Maas, P. J. M., Lubbert, Y., Westra, T., Brown Jr, K. S., Maas, P. J. M., ter Welle, B. J. H., Webber, A. C., Le Thomas, A., Waha, M., \& van der Heijden, E. (1992). Rollinia. Flora Neotropica, 1-188.

Maia, J. G. S., Andrade, E. H. A., da Silva, A. C. M., Oliveira, J., Carreira, L. M. M., \& Araújo, J. S. (2005). Leaf volatile oils from four Brazilian Xylopia species. Flavour and Fragrance Journal, 20(5), 474-477.

Mendes-Silva, I., Lopes, J. C., Silva, L. V., \& Oliveira, M. L. B. (2020). Annona. In Flora do Brasil 2020. Jardim Botânico do Rio de Janeiro.

Mimi, C. O. (2019). Araticum de terra-fria e araticum mirim: variedades de Annona emarginata (Schltdl.) H. Rainer? Universidade Estadual Paulista (UNESP).

Moreira, I. C., Lago, J. H. G., \& Roque, N. F. (2003). Alkaloid, flavonoids and terpenoids from leaves and fruits of Xylopia emarginata (Annonaceae). Biochemical Systematics and Ecology, 5(31), 535-537.

Nascimento, F. das C. do, Boaventura, M. A. D., Assunção, A. C. S., \& Pimenta, L. P. S. (2003). Acetogeninas de anonáceas isoladas de folhas de Rollinia laurifolia. Química Nova, 26(3), 319-322.

Neta, M. T. S. L., de Jesus, M. S., da Silva, J. L. A., Araujo, H. C. S., Sandes, R. D. D., Shanmugam, S., \& Narain, N. (2019). Effect of spray drying on bioactive and volatile compounds in soursop (Annona muricata) fruit pulp. Food Research International, 124, 70-77.

Oliveira, E. C. T. (2015). Produção de barra de cereal a partir da fruta do cerrado araticum (Annona crassiflora). Universidade Federal de Uberlândia.

Oliveira, E. C. T. (2019). LICOR DE ARATICUM (Annona crassiflora Mart.). Boletim Técnico IFTM, 5, 6-13.

Palarea-Albaladejo, J., \& Martín-Fernández, J. A. (2015). ZCompositions - R package for multivariate imputation of leftcensored data under a compositional approach. Chemometrics and Intelligent Laboratory Systems, 143, 85-96.

Pino, J. A. (2000). Volatile Components of Rollinia mucosa (Jacq.) Baill. Journal of Essential Oil Research, 12(1), 97-98.

Pontes, A. F., Barbosa, M. R. de V, \& Maas, P. J. M. (2004). Flora Paraibana: Annonaceae Juss. Acta Botanica Brasilica, 18(2), 281-293.

Rainer, H. (2006). Monographic studies in the genus Annona L.(Annonaceae): Inclusion of the genus Rollinia A. ST.-HIL. Annalen Des Naturhistorischen Museums in Wien. Serie B Für Botanik Und Zoologie, 191-205.

Rio Grande do Sul. (2014). DECRETO No 52.109. Declara as espécies da flora nativa ameaçadas de extinção no Estado do Rio Grande do Sul.

ttp://www.legislacao.sefaz.rs.gov.br/Site/Document.aspx?inpKey=262999\&inpCodDispositive=\&inpDsKeywords=5210 9.

Rio Grande do Sul. (2020). Atlas Socioeconômico do Rio Grande do Sul (5. Ed.). Secretaria de Planejamento, Governança e Gestão/Departamento de Planejamento Governamental. https:/atlassocioeconomico.rs.gov.atlassocioeconomico.rs.gov.br/inicial

Rohart, F., Gautier, B., Singh, A., \& Lê Cao, K.-A. (2017). mixOmics: An R package for 'omics feature selection and multiple data integration. PLoS Computational Biology, 13(11), e1005752.

Santana, K. L. de, Galvao, M. de S., Jesus, M. S. de, Nogueira, J. P., \& Narain, N. (2017). HS-SPME optimization and extraction of volatile compounds from soursop (Annona muricata L.) pulp with emphasis on their characteristic impact compounds. Food Science and Technology, 37(2), 250-260.

São José, A. R., Pires, M. de M., Freitas, A. L. G. E. de, Ribeiro, D. P., \& Perez, L. A. A. (2014). Atualidades e perspectivas 
das Anonáceas no mundo. Revista Brasileira de Fruticultura, 36(spe1), 86-93.

Scaloppi Junior, E. J., \& Martins, A. B. G. (2014). Estaquia em Anonas. Revista Brasileira de Fruticultura, 36(spe1), 147156.

Schnee, C., Köllner, T. G., Gershenzon, J., \& Degenhardt, J. (2002). The maize gene terpene synthase 1 encodes a sesquiterpene synthase catalyzing the formation of $(E)$ - $\beta$-farnesene,( $E$ )-nerolidol, and $(E, E)$-farnesol after herbivore damage. Plant Physiology, 130(4), 2049-2060.

Snoeren, T. A. (2009). Herbivore-induced indirect defense of Arabidopsis: ecogenomic approach to the role of infochemicals in parasitoid attraction. Ecogenomic approach to the role of infochemicals in parasitoid attraction. Thesis. Wageningen Universiteit.

Soares, G. L. G., Isaias, R. M. S., Gonçalves, S. J. M. R., \& Christiano, J. C. S. (2000). Alterações químicas induzidas por coccídeos galhadores (Coccoidea, Brachyscelidae) em folhas de Rollinia laurifolia Schdtl.(Annonaceae). Revista Brasileira de Zoociências, 2(1, 2).

Tairu, A. O., Hofmann, T., \& Schieberle, P. (1999). Identification of the key aroma compounds in dried fruits of Xylopia aethiopica. Perspectives on New Crops and New Uses. ASHS Press, Alexandria, VA, 474-478.

Thang, T. D., Dai, D. N., Hoi, T. M., \& Ogunwande, I. A. (2013). Study on the volatile oil contents of Annona glabra L., Annona squamosa L., Annona muricata L. and Annona reticulata L., from Vietnam. Natural Product Research, 27(13), 1232-1236.

Vredenbregt, P. (2007). The Significance of Two Homoterpenes and a Sesquiterpene in Attracting Parasitoids, Using Arabidopsis Thaliana as Model Plant.Thesis report. Wageningen Universiteit.

Walker, C. I. B., Manfron, M. P., Bortoluzzi, R. C., \& Zanetti, G. D. (2003). Análise morfo-histológica e estudo fitoquímico de Rollinia salicifolia Schlecht. IV Simpósio Brasileiro de Farmacognosia.

Wyllie, S. G., Cook, D., Brophy, J. J., \& Richter, K. M. (1987). Volatile flavor components of Annona atemoya (custard apple). Journal of Agricultural and Food Chemistry, 35(5), 768-770.

Xu, Z., Long, Y., Jiang, X., Qiao, F., Dang, Z., \& Chen, Y. (2016). Analysis of volatile components in Annona montana fruit at different developmental stages. Journal of Fruit Science, 33(8), 969-976.

Záchia, R. A. (1994). Estudos taxonômicos na família Annonaceae Juss. no Rio Grande do Sul. 1994. 366p. Mestrado Em Botânica-Instituto de Biociências, Universidade Federal Do Rio Grande Do Sul, Porto Alegre.

Záchia, R. A., \& Irgang, B. E. (1996). Delimitação de quatro espécies em Rollinia emarginata Schlecht. sensu lato (Annonaceae). Sellowia, 45(48), 73-107. 